\title{
Ismertetés és néhány reflexió Benczes István: Válság és válságrendezés a Gazdasági és Monetáris Unióban
} (Akadémiai Kiadó, Budapest, 2020, 330 oldal) címü könyvére* SOÓS KÁROLY ATTILA

A könyv az euróválságot és annak rendezését mutatja be; azt, hogy az EU hogyan kerekedett fölül a válságon. A válság kezdetén mutatkozó centrifugális tendenciákat leküzdötték kicsi, de fontos reformlépésekkel és (a bankunió fokozatos kibontakoztatása révén) az integráció jelentős mélyitésével - és az EU alaposan megváltozott ebben a folyamatban. A szerzö különös súlyt helyez munkájában a gazdasági integráció elméleteinek és más, a gazdasági integráció elemzésében hasznositható elméletek-elsösorban a liberális kormányköziség elmélete-alkalmazására. Világosan és meggyözöen mutatja ki azt, hogy a válságkezelést a tagállami kormányok közötti tárgyalások, alkudozások és megegyezések dominálták, és az EU korábban legnagyobb szerepet és súlyt képviselö nemzetek fölötti szervei - az Európai Központi Bank kivételével - vesztettek jelentöségükböl. A könyv részletesen és nagyon gondosan vizsgálja a különbözö országcsoportok által játszott szerepeket és külön Németországnak, ennek a vonakodóan és csak a gazdasági területen hegemón országnak a szerepét.

Journal of Economic Literature (JEL) kódok: E02, F02, F36, F42, F55.

Kulcsszavak: Európai Unió, euróválság, makroökonómia, liberális kormányköziség, hegemónia, Németország.

A kézirat első változata 2020. október 29-én érkezett szerkesztőségünkbe.

https://doi.org/10.47630/KULG.2020.64.11-12.79

Soós Károly Attila emeritus kutató, ny. tudományos főmunkatárs, KRTK Közgazdaságtudományi Intézet E-mail: soos.karolyattila@krtk.mta.hu 


\section{Abstract}

\section{Review of and some reflections on István Benczes: Crisis and Crisis Mana- gement in the Economic and Monetary Union}

ATTILA KÁROLY SOÓS

István Benczes's book - Crisis and Crisis Solution in the Economic and Monetary Union - is a thorough analysis of the euro crisis and of how the EU surmounted it. Centrifugal trends emerging at the beginning of the crisis were vanquished by small but important reform steps and (with the gradual development of the banking union) a significant deepening of the integration, and the EU changed importantly during this whole process. The author puts a particular accent on applying theories of economic integration and other theories applicable in the research of economic integration - first of all, liberal inter-governmentalism - in his work. He demonstrates clearly and convincingly that the treatment of the crisis was dominated by negotiations, hagglings and agreements among the governments of the member states, with the previously primary role and weight of the EU's supranational institutions - except for those of the European Central Bank - easening. The roles played by the different country groups and separately that played by Germany, the reluctantly and only in the economic field hegemonic country are being examined in detail, with elaboration in the book.

Journal of Economic Literature (JEL) codes: E02, F02, F36, F42, F55.

Keywords: European Union, euro crisis, macroeconomics, liberal inter-governmentalism, hegemony, Germany.

A 2010-es esztendő folyamán és az azt követő néhány évben is néha többé, máskor kevésbé, de mindig volt okunk félni attól, hogy az eurózóna déli országaiban és Írországban kibontakozó súlyos államadósság-válság maga alá temeti az eurót - a Gazdasági és Monetáris Uniót (GMU) -, és ezzel nehezen kiheverhető csapást mér az Európai Unióra, sőt még általánosabban az európai integráció eszméjére is. Azt persze már tudjuk, hogy nem így történt. Benczes István könyve azt világítja meg nekünk, hogy miért, hogyan történt másképp: hogyan élte túl az integráció a válságot. Megtudjuk, hogy az eurózónának és így az EU-nak is alaposan meg kellett változnia ahhoz, hogy fönnmaradjon; változási, fejlődési mechanizmusainak még inkább át kellett alakulniuk, a szerző szavai szerint az EU „gazdasági kormányzási rendszere összetettebbé, színesebbé és hatékonyabbá vált” (Benczes, 2020:25). Alkalmazkodóképesebb, erősebb lett ez az integráció.

Az ehhez a következtetéshez elvezető elemzés nem korlátozódik a monetáris unió válságára és a válság kezelésére, hanem kiterjed az integrációelméletek és az integrációs folyamatok elemzésére használt, használható más elméletek történetére 
is. Ami természetesen nem teszi a könyvet sem rövidebb, sem könnyebb olvasmánynyá. Azonban a történet így kerek; így érthetjük azt jobban meg, így tanulhatunk sokat belöle.

A különféle elméletek szerepe, a változások elemzésére való alkalmassága változó. Újabbak jelennek meg anélkül, hogy teljesen kiszoríthatnák a régieket. Benczes írásában a legfontosabb ilyen változás az, amikor a válságkezelés 2010. évi elsődleges (majdnem kizárólagos) föladattá válásához kapcsolódva megszűnt a neofunkcionalizmus primátusa, és előtérbe került egy két évtizedes, de addig kevéssé alkalmazott versenytárs: a liberális kormányköziség elmélete.

Miröl is van itt szó? Nos, a neofunkcionalizmus (az integrációelmélet területén) a nemzetek fölötti intézmények egymásba kapcsolódó, egymásból következő létrejöttének elmélete. A könyvben szereplő fontos példa erre a (jó magyar szóval spillovernek nevezett) jelenségre az, hogy a közös agrárpolitika keretében nyújtott pénzbeli támogatások rendszerének müködését érthető okokból nagyon zavarták a közösségi tagországok valutáinak egymás közötti árfolyam-ingadozásai, és ez lett a közös valuta - és vele a nemzetek fölötti Európai Központi Bank (EKB) - létrehozásának (egyik) oka. Az ilyen spilloverek az Európai Szén- és Acélközösség 1951. évi létrehozatalát követő fél évszázadban az európai integráció fejlődésének legfontosabb motorjai közé tartoztak.

Amikor azonban az elbukott alkotmányozási folyamat, és a Lisszaboni Szerződés elfogadásának nehézségei után elóállt és cselekvést követelt az euróválság, akkor nem látszott lehetőség újabb nemzetek fölötti intézmény létrehozására. „A tagállami vezetők által levezényelt, a tradicionális szupranacionális elitet, ha nem is mellőző, de háttérbe szorító válságrendezés" (Benczes, 2020:27) valósult meg, és a létrejött intézmények (az adósságválságba kerülő vagy az által fenyegetett eurózóna-tagállamok kedvező föltételű hitelekkel való megtámogatásra hivatott Európai Stabilitási Mechanizmus, az ESM és annak előintézményei) a tagállamok kormányai közötti egyezményeken alapultak. Ez az új rendszer egyáltalán nem jelentett visszarendeződést az európai integráció folyamatában. A liberális kormányköziség legjelentősebb képviselője Andrew Moravcsik. Az elmélet nem létezett az európai integráció első évtizedeiben, de lényegében az akkori fejlődésre is alkalmazható lenne: középponti állítása az, hogy az Európai Unió nagy kérdései tagállami alkukban dőlnek el. A szupranacionális elitek és az EU intézményei így nem okai (mint azt a neofunkcionalizmus föltételezi), hanem következményei az integrációs folyamatnak, amelyet a tagállamok mozgatnak. A liberális kormányköziség elmélete nagy jelentőséget tulajdonít a társadalmi szereplők preferenciáinak, amelyekből az álla- 
mi akarat összeáll. Ha a társadalom meghatározó, befolyással bíró erőinek haszna származik a GMU müködéséből, akkor az államok vezetői is támogatni fogják a monetáris együttmüködést. Megrendülni akkor fog az euró, ha a használatát nem támogatják az üzleti és kormányzati körök.

Benczes elemzése kisebb-nagyobb mértékben további elméletekre is támaszkodik. Ilyen például a történeti institucionalizmus, amely az egyszer létrehozott, müködő intézmények további utat, változásokat befolyásoló szerepével (útfüggőség) foglalkozik; a (neo)realizmus, amely azt vizsgálja, hogy az anarchia mint a nemzetközi politika rendezőelve hogyan strukturálja az államok lehetőségeit és interakcióit; valamint a neoliberális institucionalizmus, amely az együttmüködés elmélete. Mégis a liberális kormányköziség van az elemzés előterében, mert a válságkezelés legnagyobb részben ehhez volt kapcsolható.

A könyv módszertani részeit tartalmazó 2. és 3. fejezet után a 4 . fejezet az eurózónában a válság alatt mutatkozó centrifugális tendenciákkal, dezintegrációs veszélyekkel foglalkozik. Amikor 2010 és 2012 között több - elsősorban a görög, a portugál és az ír - kormányzat adósságválságba került, széles körben elfogadott nézet lett az, hogy a helyes (Pareto-optimális) megoldás a fiskális és politikai unió megteremtése volna, de ilyet a tagállamok nem vállaltak föl. A föl nem vállalt nagy átalakítás helyett kisebb, inkrementális reformok történtek; ezeket - a kis lépések stratégiáját - tárgyalja az 5. fejezet. Ezzel a stratégiával az EU - amennyiben egyáltalán államként, annyiban - alapvetően szabályozó államként müködött. Ami azt jelenti, hogy vonakodott olyan újraelosztási problémák fölvállalásától, amelyek túlmentek volna a nagyon korlátozott terjedelmü és rendeltetésű közös költségvetés keretein. Az adósságválságba került szuveréneket kimentették a bajból, és az euró fönntartása nem kérdőjeleződött meg, de az ilyen akciókhoz a szabályozás szigorítását is hozzákapcsolták, ettől remélve azt, hogy további hasonló bajok nem lesznek. A fizetésképtelenség által fenyegetett államokkal kapcsolatban szokásos (kötvény)piaci bizonytalanságokat itt az is tetézte, hogy sokáig nem lehetett tudni, az eurózóna tagállamai között az önzés vagy a szolidaritás fog-e fölülkerekedni. A döntéseket egymással kialkudó tagállami vezetők körein kívül fölmerült az eurózóna szétesésének vagy egyes tagállamok kilépésének gondolata is (amit egyebek mellett az euró árfolyam-ingadozásai is tükröztek), de az ilyen visszafordulás nagyon költséges lett volna; ezt nem vállalták. Viszont mindig csak annyi reformot valósítottak meg, amennyi az épp fenyegető válság elhárításához szükséges volt. Annyit olyan értelemben is, hogy annál nem kevesebbet. Fontos példája ennek az, hogy Németország lényegében „,beáldozta” a Lisszaboni Szerződés (német követelésre született) 
125. cikk 1 . bekezdését, amely tiltja, hogy egy tagállam egy másik tagállam fiskális tartozását bármilyen mértékben vagy formában kiegyenlítse. (Noha volt némi vita arról, hogy tényleg történt-e „beáldozás”, ugyanis a Szerződés nem tiltja kifejezetten a tagállamok közötti - akár kimentési célú - hitelnyújtást, tehát azt a formát, amelyben a segítséget nyújtották.)

A kimentéssel kapcsolatos alku éles vitákkal sokáig húzódott. A viták értelmezésében segíthet a jól ismert Gyáva nyúl játék vagy még inkább az ún. kooperációs játék modellje. Az utóbbi kimerítő háborús vagy időhúzásos játék, amelyben mindkét fél arra spekulál, hogy az időhúzással ő nyer. Ezt a modellt alkalmazzák például koalíciós kormányok viselkedésére olyan helyzetekben, amikor hosszú ideig nem reagálnak egy negatív fiskális sokkra, mert veszít, aki először lép. A játékban a két csoportot az adós és a hitelező államok alkották. Az adósok nem voltak eszköztelenek, mert a kilépésük vagy az államcsődjük az eurózóna stabilitását megingatta volna. (De mivel az államcsődnek haszna nincs, az azzal való fenyegetőzés kevéssé lehetett hatékony.)

A német kormány fölvetett egy radikálisabb javaslatot is a válság kezelésére: a Lisszaboni Szerződés módosításával létrehozhattak volna egy az IMF-hez hasonló Európai Valutaalapot (EMF) az adósságproblémák kezelésére, ezt azonban a tagállamok, félve a módosított Szerződés ratifikálása körül várható bonyodalmaktól, nem vállalták (és akkor a gondolatot később fölkaroló Európai Bizottság sem támogatta). Ehelyett elöször 2010. május 2-án - az elhúzódó viták közben, már-már végveszélyhelyzetben - az eurózóna tagállamai közvetlen hitelt nyújtottak Görögországnak mindössze 30 milliárd euró értékben. Még abban a hónapban létrejött az ESM már említett két ideiglenes elődintézménye (az EFSM és az EFSF), és ezek az IMF-fel együtt összesen 750 milliárd euró hitelt nyújtottak Görögországnak. Az ideiglenes, nagyon rögtönzés jellegủ megoldás drága (magas kamatlábú) volt, ezért nem segítette az adósságállomány növekedésének megfékezését, így a görög kincstár által fizetett kamatfelárak sem csökkentek. Maga az ESM, föleg jogi bonyodalmak miatt, csak két évvel később alakult meg, amikor elöintézményei, az IMF-fel együtt, már a portugál és az ír kormánynak nyújtott hiteleken is túl voltak. Azonban az ESM fontos, tartós, a tagállami bankválságok kezelésére is alkalmassá tett intézmény; centralizációt nem jelentő, az integrációt nem mélyítő, de a tagállamok együttmüködéséből fakadó és azt javító intézmény példája. Segítségnyújtása - főleg német követelésre - szigorú föltételekhez van kötve. Csak olyan állam kaphat tőle (nagyon alacsony kamatú) hitelt, amely új kötvényeit kollektív föllépési klauzulával bocsátja ki (ez kötelezi a kötvény mindenkori tulajdonosát arra, hogy az adós állam fizetö- 
képességi zavara esetén elfogadja a tulajdonosok minősített többsége és az állam közötti fizetéskönnyítési megállapodást). További föltétel az, hogy az államadósság fönntartható legyen, és hogy valóban az-e, arról az EB, az EKB és az IMF képviselőiből álló „trojka” dönt. Német részről azt is követelték, hogy az ESM működési szabályzata terjedjen ki államcsődök kezelésére vonatkozó szabályokra, továbbá a megsegített tagállamok költségvetési politikai mozgástere formális korlátozásának lehetőségére is, de ezeket a követeléseket a többség nem fogadta el.

A válságkezelés rendszerét tehát lényegében az alkalmazása közben alakították ki (a semmiből). A válság megelőzését célzó szabályokat már az euró bevezetésére készülve fölállítottak (Stabilitási és Növekedési Egyezmény, SNE), de szükségesnek látszott ezek kiegészítése, szigorítása. Az ún. európai szemeszterről szóló 2011. szeptemberi rendelet kiterjesztette, egységes rendszerbe foglalta a makrogazdasági felügyeletet és ellenőrzést. A három hónappal később hatályba lépett ún. hatos törvénycsomag (öt rendelet és egy irányelv) részben az SNE szabályait szigorította, részben (a közpénzügyek területén túllépve) a versenyképességet és a külső fizetési (egyensúlyi) pozíciót érintő szabályokat is meghatározott. A 2013 májusától hatályos ún. kettős csomag két uniós rendelet, amelyek szerint a bajba került és segítséget kapó tagállamoknak a Bizottság útmutatása alapján szigorú kiigazítási programot kell elfogadniuk, hogy ne veszélyeztessék az eurózóna egészének stabilitását.

Azonban a szabályalapú gazdaságpolitikai koordináció bebetonozását legkeményebben a 2013 januárjában hatályba lépett, a GMU-beli stabilitásról, koordinációról és kormányzásról szóló szerződés tartalmazta. Ezt angol nevének rövidítésével TSCG-ként vagy fiskális egyezményként ismerjük (szerzőnk a kialakuló rossz szokást követve fiskális paktumról ír; a paktum a mi nyelvünkben pejoratív értelmü szó). Ez az egyezmény már a konjunkturális hatásoktól megtisztított nemzeti költségvetési egyenlegre (az ún. strukturális egyenlegre) is elöír szabályt. A tényleges egyenleg rossz konjunktúrában rosszabb lehet, jó konjunktúrában jobbnak kell lennie, de a strukturális értéke sohasem lehet a GDP mínusz fél százalékánál rosszabb. És itt már született adósságszabály is (ilyen korábban csak a „maastrichti” befogadási szabályok között volt): most azt írták elő, hogy az államadósságnak a GDP 60 százaléka fölötti részét (ha van ilyen) évente az egyhuszad részével csökkenteni kell.

A fiskális egyezmény kormányközi megállapodás volt; az EB javaslata ellenére nem emelték be a Lisszaboni Szerződésbe. Az Európai Tanács (a miniszterelnökök) súlyát növelte az EB-vel szemben. Az Európai Bíróság (European Court of Justice, ECJ) szerepet kapott annak az elöírásának a betartatásában, amely szerint az aláíró felek kötelesek saját, nemzeti szintű költségvetési egyensúlyszabályt is elfogadni, 
lehetőleg az alkotmányukban vagy más magasabb szintű jogszabályban. Az ECJ ilyen szerepe nem jelentette a nemzetek fölötti centralizáció erősítését, de az egyezmény integrációt erősítő szerepe nyilvánvaló. Az előírások betartatásában azonban mutatkoztak bizonytalanságok: 2016-ban Portugáliáról és Spanyolországról is megállapították, hogy túl keveset tettek deficitjük csökkentésére, de az elvileg automatikusan járó büntetés kiszabása helyett a Tanács új határidőt szabott meg nekik a föladat végrehajtására. A hatos törvénycsomag külső fizetési (egyensúlyi) pozíciót érintő szabálya elvben a legnagyobb hitelező Németországot folyó fizetési mérlegének rontására, a déli államokat mérlegük javítására kötelezné; Németország viselkedése alapján nehéz lenne föltételezni, hogy szándékosan törekedne e kötelezettsége teljesítésére. A szükséges változást inkább a déli államok versenyképességének javításától lehet várni.

A 6. fejezet témája az, hogy van-e hegemón az EU-ban. A hegemón stabilitás elmélete szerint a hegemón olyan ország, amely dominanciájával biztosítja a nemzetközi viszonyok stabilitását, ilyen értelemben kollektív javakat biztosít. (Az elmélet liberális változatához Robert Keohane hozzáteszi azt is, hogy a hegemónt az különbözteti meg a többi államtól, hogy képessé válik a nemzetközi rendszer alapvető ismérve, az anarchia állapotának olyan irányú befolyásolására, hogy abból a rendszer minden szereplöje hasznot húzhat a stabilitás révén.) Az persze nyilvánvaló, hogy az EU-ban ilyen szerepe csak Németországnak lehet(ne), és a könyv kontextusában a hegemónia azt jelentené, hogy ez az ország elkötelezi magát a válságrendezés költségeinek vállalására. Németország azonban egyrészt a Lisszaboni Szerződés már említett 125. cikk 1. bekezdése értelmében nem jogosult ilyen terhek vállalására, másrészt az EU legerősebb gazdaságaként nem kíván hegemónként tekinteni önmagára; egy kicsit sem szeretne összetéveszthető lenni a második világháború előtti önmagával.

Végül is Németország vonakodó hegemónnak tekinthető. Vonakodó annyiban, amennyiben csak gazdasági területen hajlandó effajta szerepet vállalni. Ezzel szemben kül- és biztonságpolitikai területen nem biztosít kollektív javakat, időnként ki is marad közös ügyekböl, noha általában tétlennek nem mondható; Benczes utal a 2014-es krími válság kapcsán folytatott politikájára vagy a menekültválság kezelésében játszott erkölcsi vezető szerepére. A „vonakodó” jelző markánsabb értelmezése magával az euróválság kezelésével összefüggésben az, hogy a kívánatos megoldásokat illetően Németország preferenciái nem estek egybe a válságországokéival.

A német kormány csak akkor változtatott a bárminemű kimentést elutasító álláspontján, amikor már az eurózóna stabilitása került veszélybe, és akkor a segítség- 
nyújtást függővé tette egyebek mellett szigorú megszorító intézkedések elfogadásától is. Ebben a német politikában az elemzők egy része erőfölénnyel való visszaélést látott, a szolidaritás hiányáról, rövidlátásról vagy egyszerűen elhibázott politikáról beszélt. Német értelmezés szerint azonban itt a helyes irányban tett lépések sorozatáról és az európai integráció jövője iránt érzett felelősségről, a jövőt biztosító szabályok betartatásáról volt szó.

Azonban a német Európa-politika jövőbeli alakulásával kapcsolatban vannak kérdőjelek. Korábban a német politikai elit nagyfokú autonómiát élvezett ezen a területen, de újabban jobban figyelnie kell a szavazópolgárok viselkedésére, akik nem elhanyagolható része az Alternative für Deutschland (AfD) felé fordult. És fontos német intézmények (a Bundesbank és az Alkotmánybíróság) is korlátot jelentenek a döntéshozatalban. Európa jövőjét illetően a legfontosabb kihívások egyikét a német belső politika alakulása jelenti.

A 7. fejezet két olyan területtel foglalkozik, amelyeken a válság kapcsán az integráció jelentős mélyülését tűzték ki célul. Az egyiken - a bankügyben - ez sikerült, a másikon - a gazdasági (ezen belül is a fiskális unió) megteremtésében - lényegében nem.

A Lehman Brothers csődje után a kormányfők Tanácsa hangsúlyozta a koordinált cselekvés fontosságát a pénzügyi válság elhárítására, de sem akkor, sem később nem sikerült megállapodniuk a bajba jutott pénzintézetek együttes kimentéséről, ami már csak azért sem lett volna indokolatlan, mert a bankoknak az EU egységes piacán müködhettek, és közülük sok élt is ezzel a lehetőséggel. Igaz, ugyanakkor a banktevékenység szabályozása nemzeti szintű maradt; mindez így együtt természetesen problematikus volt.

A bankközi hitelpiacok az önbeteljesítő kölcsönös bizalmatlansággal befagytak; ez a viszonylag erősebb bankrendszerrel rendelkező államokat is kihívás elé állította. A bankok más lehetőség híján saját kormányukhoz fordultak segítségért. Ha ezt megkapták, tehát kormányuk hitelt vett föl a megsegítésükre, azzal romlott annak hitelképessége, és csökkent az általa kibocsátott, az ő tulajdonukban lévő kötvények értéke, ezért további segítséget kellett kérniük a kormányuktól. És így tovább, itt egy ördögi körröl van szó. A válságországokat - leszámítva Görögországot, amely a korábbi években nagyon felelőtlen költségvetési politikát folytatott - nagyobb részben ez a folyamat tette válságországokká.

A probléma megfontolandóvá tette a banki kockázatok közös kezelését. A megoldást a bankunió jelentette, amelyröl már 2010-től beszéltek, de tényleges lépések csak 2012-ben kezdődtek ezen a területen. Ezekkel a tagállamok megerősítették az 
integráció melletti elkötelezettségüket. Ugyanakkor nem a megszokott módon jártak el. Nem erősítették a meglévő nemzetek fölötti szerveket: az EB-t és az ECJ-t. Ehelyett részben a GMU új központi szervének, az EKB-nak adtak új funkciókat, részben új intézményeket (Európai Bankhatóság, Egységes Szanálási Testület) hoztak létre. Az egységes bankfelügyeleti mechanizmus feje (2014 decemberétől) az EKB lett, de ez a tevékenysége, amelyet a nemzeti központi bankokkal együttmüködésben gyakorol, csak 120 nagybankra terjed ki (a többiek nemzeti felügyelet alatt maradtak). Az egységes szanálási mechanizmus kialakítása több vitával járt. Németország ellenezte az olyan megoldást, amely jelentős hatalmat adott volna az EB-nek. Az egységes rendszer helyett inkább nemzeti szanálási alapok harmonizált rendszerének kialakítását szerette volna (bankrendszerében nagy a súlya a köztulajdonú bankoknak, amelyekhez külön szanálási rendszer kapcsolódik). A szanáláshoz kapcsolódóan a hitelezők és a részvényesek bevonásának olyan szigorú szabályait harcolták ki, amelyek hosszabb távra jobb rendszert jelentenek, de növelik a nehézségekkel küszködő tagállamoktól a piacon elvárt kamatfelárat, nehezítve ezzel adósságaik kezelését. Enélkül a bankreform-lépéssorozat nélkül a GMU mára életképtelenné vált volna. Azonban a neofunkcionalista megközelítés még most is arra figyelmeztet, hogy a bankunió még nem befejezett. Hiányzik egyrészt a közös betétvédelem és a végső biztosítékot kínáló közös költségvetési védőháló.

A bankügyhöz tartoznak még a bankszerkezeti dilemma ügyei. A nemzetközi pénzügyi és gazdasági válság fölélesztette a betéti-hitelezési és a befektetési banki tevékenység szétválasztására irányuló (ilyen helyzetekben mindig megjelenő) törekvéseket. Az USA-ban (2010-ben) és néhány EU-tagállamban törvényt is hoztak ebben a szellemben. Az EB 2014-ben javasolta a saját számlás kereskedelmi tevékenység megtiltását és az egyéb kereskedelmi tevékenységek elválasztását a betétihitelezési tevékenységtől. A Tanács a tilalom helyett (bankcsoporton belüli) elválasztást javasolt a saját számlás kereskedésnél, az egyéb kereskedelmi tevékenységek korlátozását pedig nem is tartotta szükségesnek. Jelentős mértékủ, a bankrendszer stabilitását potenciálisan veszélyeztető saját számlás kereskedelmi tevékenységet föleg néhány német és francia nagybank folytatott. Ezek jó piaci pozíciókba kerültek és sokat kerestek ezzel, úgyhogy a két érintett kormány, megelőzve az eurózónaszintủ szabályozást, összehangoltan szabályozta a tevékenységüket, jóval kevésbé szigorúan, mint ahogyan az EB - az EU szintjén - javasolta. 2017-ben a Bizottság elállt a saját javaslatától.

A bankszerkezeti szabályozás kimenetele tehát nem igazán szerencsés, de öszszességében a bankreform, főleg a bankunión belüli egységes szanálási mechaniz- 
mus létrejötte az európai integráció egyik legnagyobb sikere; rendkívül fontos lépés a szupranacionalizáció felé. Ezt az tette lehetővé, hogy a tagállamok, elsősorban Németország, készek voltak módosítani merev álláspontjaikon, amit kikövetelt a korábbi rendszer elhibázottsága.

Ami most már a fiskális uniót illeti, eleve problémát jelent, hogy nem egyértelmú maga a fogalom. Tekinthető fiskális uniónak a fiskális szabályok rendszere (amelyet a válságkezelés folyamán továbbfejlesztettek). Egy másik lehetséges értelmezésben ez kiegészül egy állandó kimentési alap létezésével (ilyen lett az ESM). Ennél is több lenne a közös tehermegosztás. Ide tartozna az eurózóna-tagállamok által közösen kibocsátott, az EU nemzetek fölötti szervei által többször javasolt eurókötvény, amelyet Németország sohasem fogadott el. (Legalábbis a könyv megjelenése előtt. Az Európai Helyreállítási Terv Európai Tanács által elfogadott pénzügyi alapjának létrehozatala azonban bizonyára szükségessé fogja tenni valami ilyen jellegü kötvény használatát.)

Szakértő intézmények, csoportok többször fölvetették a tagállamokat érintő aszimmetrikus sokkokkal kapcsolatos kockázatok megosztásának (a dekonjunktúra által sújtott tagországok megsegítésének) szükségességét. Általában elfogadták azt, hogy bárminemü ilyen rendszer elfogadásának föltétele a költségvetési fegyelem intézményes biztosítása. Németország az utóbbit csak azzal látta volna megvalósultnak, ha a segítséget kapó ország fiskális szuverenitását korlátozzák. Ezt azonban mások kifogásolták, és ezzel megfeneklett a kezdeményezés.

A fiskális unió kialakításának az is jelentős korlátja, hogy az adófilozófiák és az adórendszerek, de ugyanígy az állami kiadások szerkezetei is jelentősen különböznek az EU (és ezen belül az eurózóna) országai között.

A könyv tartalmát összefoglaló és kitekintést adó 8 . fejezetből három pontot fontos kiemelni.

Egyrészt a szerző szerint a mindkét félnek jóléti veszteséget okozó brexit után további ország kilépése az EU-ból nem várható, és nem várható kilépés az eurózónából sem. Másrészt a válság kezelése kétféle értelemben is sikeres volt. Nemcsak egyben tartotta a megroppanni készülő eurózónát, de a megoldás föllelésében olyan közösség képét vázolta föl, amely hajlandó innovatív módon megújulni. Végül, noha a válságrendezés során nem valósult meg a lojalitás vagy a politikai várakozások áthelyeződése a tagállamoktól a központ felé, az újításoknak köszönhetően az eurózóna így is minden korábbinál erősebbé, válságállóbbá vált.

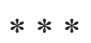


A szerző maga említi könyvének hozzáadott értékeként az események, fejlemények saját szempontrendszere szerinti szisztematikus kategorizálását, és valóban, a nemzetek fölötti megoldások, intézmények kormányköziekkel való következetes szembeállítása közelebb visz a történtek megértéséhez. Az elemzés alapossága, az irodalom gondos földolgozása a könyvet fontossá teszi mindazok számra, akik meg akarják érteni az eurózóna történetét, amely a 2000-es évek közepének bővítése után szinte egyet jelentett az EU történetével.

Bíráló megjegyzéseket - azon túlmenően, hogy hiányolok a könyvből egy névés tárgymutatót - három szempontból teszek. Egyrészt a válságországokkal szembeni bánásmód kapcsán fölvetem bizonyos inkorrektségek problémáját. Másrészt keveslem a kifejezetten közgazdasági elemzést. Harmadrészt a monetáris és a fiskális unió közötti kapcsolatot a szerzőtől eltérően látom.

1. Egy lehetséges félreértést elkerülendő leszögezem, hogy egyetértek a szerzővel Németország válságkezelésben, általában az európai integrációban játszott szerepének alapvetően messzemenően pozitív értékelésében; elismerem, hogy Németország áldozatokat hozott az eurózóna megmentésének érdekében. Ugyanakkor nagyon szerencsétlennek tartom azt, hogy az adósságválságba került országok - föleg Görögország és Írország - helyzetének rendezésébe kevéssé vonták be a nekik hitelező bankokat, köztük a nekik legnagyobb öszszegeket hitelező német és francia bankokat. Nem vitatom, hogy Görögország polgárainak meg kellett sínyleniük azt, hogy korábban fiskálisan szélsőségesen felelőtlen kormányokat választottak maguknak. Azonban 2010-ben mindenképp csökkenteni kellett volna a képtelenül magas, kezelhetetlen görög államadósságot (amit az IMF késhegyig menő vitában, eredménytelenül követelt az EU vezetőitől, lásd Blustein, 2016). Ehelyett inkább megkímélték a potenciális veszteségektől azokat a nagybankokat, amelyek hiteleik nyújtásakor nyilvánvalóan tudták, hogy a görög államadósság adatait a kormányok meghamisították, és újonnan vállalt kötelezettségeiket nem fogják tudni teljesíteni. De persze a német és a francia kormányok tulajdonképpen nem a bankokat védték, hanem önmagukat, mert a csődhelyzetbe kerülő bankokat nekik kellett volna föltőkésíteniük. Ez a szégyenfolt hozzátartozik az euróválság kezelésének történetéhez.

2. Noha a könyvböl kiderül, hogy témájával kapcsolatban nemigen vannak olyan közgazdasági nézetek, elméletek, amelyeket a szerző nem ismerne vagy nem értene, közgazdasági fejtegetésekkel mégsem nagyon kényezteti el az olvasót. Több fért volna ilyesmiből abba a könyvbe, amely a válságkezelés vitáit, 
dilemmáit, politológiai és más nem közgazdasági elméleteit ilyen részletesen tárgyalja.

3. Az elöbb említett hiátus legfőbb példája a monetáris és a fiskális unió összefüggése. Természetesen Benczes könyve messze fölötte van annak a - megszokottnak mondható - színvonalnak, amely a monetáris és a fiskális uniót egymástól elválaszthatatlan sziámi ikreknek tekinti, szentírásként kezelve Robert Mundell optimális valutaterület-elméletét (Mundell, 1961). A könyv természetesen tárgyalja Mundell egy másik, homlokegyenest ellentétes következtetésekre vezető írását is (amelyet McKinnon [2004] Mundell II-nek nevez); emellett az eurózónában (az EU-ban) a tulajdonképpeni fiskális uniót egy alfejezet címében lehetetlennek nyilvánítja anélkül, hogy emiatt fenyegetve látná az euró jövőjét. Mégis összekapcsolja a monetáris uniót a fiskálissal például a 266-267. oldalon. Ez az összekapcsolás szerintem nem magától értetődő. A monetáris uniót lehetővé tette a monetáris politika technokratizálódása (a központi bankok világméretü függetlenedése). Ezzel szemben a fiskális politika par excellence politikai maradt; politikai unió nélkül - amelynek híre-hamva sincs - nem egységesülhet. Willem Buiter (1997) már 1997-ben, megfelelő érvekkel alátámasztva, élesen vitatta azt a tételt, hogy a monetáris unió müködéséhez szükség lenne fiskális unióra. Nagyon kétséges az, hogy az aszimmetrikus sokkok kezeléséhez szükséges lenne egy jelentős központi költségvetéssel rendelkező fiskális unió. Az USA-ra való gyakori hivatkozás ebben a kérdésben egyszerüen téves. Azon akciók terjedelme, amelyek az USA szövetségi költségvetésében kifejezetten az államok (régiók) közötti konjunktúrakülönbségek hatásainak csökkentésére irányulnak, nagyon csekély, és a szövetségi költségvetés általános újraelosztási tevékenységének ilyen jellegü hatása is sokkal kisebb, mint az egységes hitel- és tőkepiacok ilyen kiegyenlítő hatása (Asdrubali et al., 1996; Hoffmann \& Sorensen, 2012), és természetesen az euró létrejötte, a bankunió eredményei és a tőkepiaci unió elhatározott fejlesztése nagy lépések a hasonló hatásokkal kecsegtető egységes európai hitel- és tőkepiac megteremtése felé. Nem állítható tehát egyértelmủen, hogy a monetáris integráció sokkal több fiskális integrációt tesz szükségessé, mint amennyi az ESM létrejöttével megvalósult. Persze a fiskális integrációról folytatandó alaposabb vitának nem itt van a helye. 


\section{Hivatkozások}

Asdrubali, P., Sørensen, B. E. \& Yosha, O. (1996). Channels of Interstate Risk Sharing: United States 1963-1990, The Quarterly Journal of Economics, 111(4), 1081-1110.

Benczes, I. (2020). Válság és válságrendezés a Gazdasági és Monetáris Unióban. Akadémiai Kiadó, Budapest.

Blustein, P. (2016). Laid Low. Inside the Crisis that Overwhelmed Europe and the IMF. Center for International Governance Innovation, Waterloo, Canada.

Buiter, W. H. (1997). The Economic Case for Monetary Union in the European Union, Review of International Economics, 5(5), 10-35.

Hoffmann, B. \& Sorensen, M. (2012). Don't expect too much from EZ fiscal union - and complete the unfinished integration of European capital markets! Vox CEPR Policy Portal, https://voxeu. org/article/hedging-macroeconomic-risk-eurozone-fiscal-union-versus-capital-markets, letöltve 2018. november 23.

McKinnon, R. (2004). Optimum Currency Areas and Key Currencies. Mundell I versus Mundell II, Journal of Common Market Studies, 42(4), 689-715.

Mundell, R. A. (1961). A Theory of Optimum Currency Areas, American Economic Review, 51(4), $657-665$. 